Civil Engineering

Volume 170 Issue CE6

Crossrail programme organisation and management for delivering London's Elizabeth line

Wright, Palczynski and ten Have
Proceedings of the Institution of Civil Engineers Civil Engineering 170 November 2017 Issue CE6 Pages 23-33 http://dx.doi.org/10.1680/jcien.17.00016 Paper 1700016

Received 07/03/2017 Accepted 25/05/2017 Keywords: codes of practice and standards/project management i

\title{
Crossrail programme organisation and management for delivering London's Elizabeth line
}

1 Simon Wright BSC, CEng, FICE, OBE Programme Director, Crossrail Limited, UK

2 Richard Palczynski BEng, CEng, FICE, FAPM

Programme Controls Director, Crossrail Limited, UK
3 Patrick ten Have

Consultant

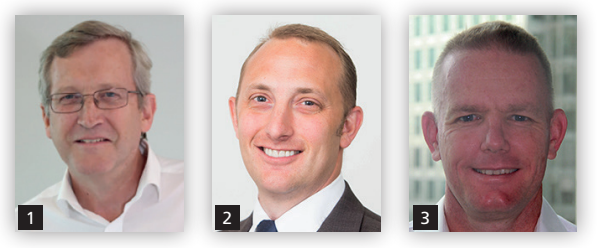

The Crossrail Act for an east-west railway across London was given royal assent in 2008 and construction started on what will become the new Elizabeth line in 2009. This paper looks at how Crossrail Limited, the client delivery organisation, was assembled, how it evolved and what programme and project management practices it deployed. Its objectives were to deliver the project Sponsors' Requirements and maintain industry-leading performance for health and safety, environmental and sustainability performance as well as cost and schedule management on one of the UK's most eagerly awaited and most complex pieces of infrastructure.

\section{Introduction}

The Crossrail project to deliver London's new Elizabeth line (as outlined in Figure 1) is nearing completion. By the time the new line is operating to all destinations in December 2019, over 55000 people will have played their part in its delivery.

Crossrail Limited, the publicly owned delivery organisation, was set up to be accountable to its sponsors, Transport for London (TfL) and the Department for Transport (DfT), for $£ 14.8$ billion of construction work through one of the world's busiest cities.

This paper describes how the organisation tackled programme organisation and management, resolving the complexity of a very large-scale project to keep the project on time and within the agreed funding envelope.

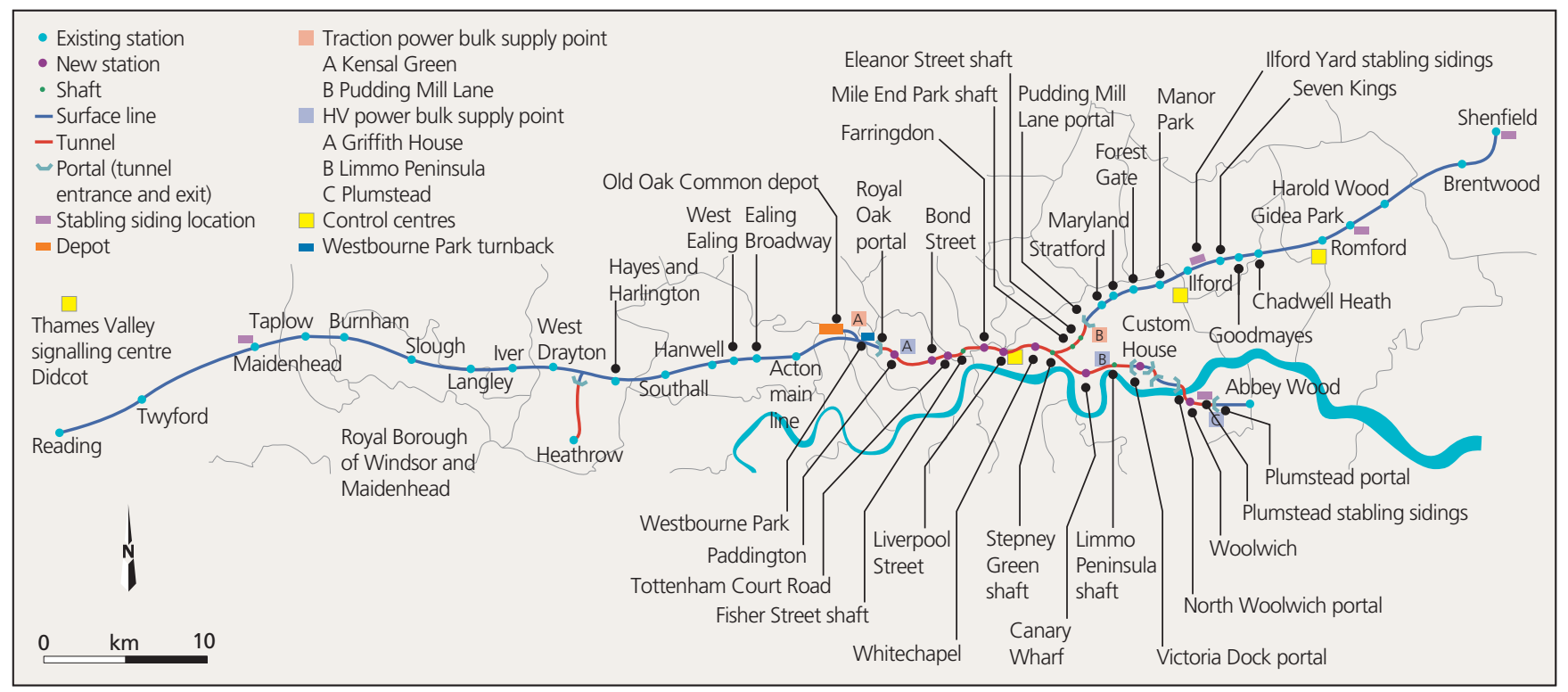

Figure 1. Scope of the project 
Crossrail programme organisation and management for delivering London's Elizabeth line

Wright, Palczynski and ten Have

\section{Delivery vehicle}

Crossrail Limited, a wholly owned subsidiary of TfL, was established in 2008 by its joint sponsors as the successor to the previous jointly owned development company Cross London Rail Links Limited. It was set up as a special-purpose company specifically to design and deliver the Crossrail project, that is an endto-end railway transport system capable of operating services between Reading and Heathrow in the west and Shenfield and Abbey Wood in the east. On phased completion, the new Elizabeth line railway will be handed over to TfL's subsidiaries, Rail for London and London Underground, in five stages and run as part of the TfL network.

Crossrail Limited's mandate or mission from its sponsors was 'to deliver a world-class railway that fast-tracks the progress of London'. This all-encompassing statement was further developed and adopted as the organisation's vision, 'moving London forward'. The vision underpinned the values and these have aligned the objectives of the multi-layered client organisation and its supply chain.

The Crossrail values are

- Safety - we put safety first.

- Inspiration - it's in our power to change things for the better.

- Respect - we treat people as we'd like to be treated.

- Collaboration - we're stronger together.

- Integrity - we keep our promises.

These values, captured in a booklet that all joiners received, became central to the company's culture and contributed to the creation of the high-performing team, which was essential to running an enterprise of the magnitude and complexity of Crossrail.

The Crossrail Act 2008 received royal assent in July 2008, giving the UK government's Secretary of State for Transport powers to acquire land, and to construct and maintain the railway. Crossrail Limited was formed as the nominated undertaker to put in place an organisation capable of discharging the obligations and undertakings as set out within the Act. All of this was to be carried out such that the project remained within its $£ 14.8$ billion funding envelope and the railway opened on time.

In developing a delivery strategy, it was recognised that the client organisation would need to be augmented with sufficiently experienced staff to deal with the scale and complexity throughout the 10 year project lifecycle. This need existed at both a programme management and project management level and resulted in Crossrail Limited awarding two delivery partner contracts in early 2009.

The first partner contract was awarded to Transcend, a joint venture between Aecom, CH2M Hill and the Nichols Group, with the specific purpose of acting as the programme partner helping Crossrail Limited fulfil its obligations to deliver safely the overall programme to time, to the desired standard and within budget, as well as supplementing the core Crossrail Limited team with technical capability.

The second partner contract was awarded to Bechtel, the project delivery partner, supported by its nominated sub-suppliers Halcrow and Systra. Under this contract the project delivery partner provided the capability to drive delivery of the central section between Westbourne Park and Stratford/Plumstead.

For the first 2 years of their appointments, both partners worked with the client to set up the project including its management systems and controls functions. Mobilising the large workforce in the time needed for these tasks was a major challenge.

Furthermore, the project had several other partners in both the public and private sectors. Although not under the direct management control of Crossrail Limited, they were responsible through contract agreement for delivery of significant parts of the project, as set out in Figure 2.

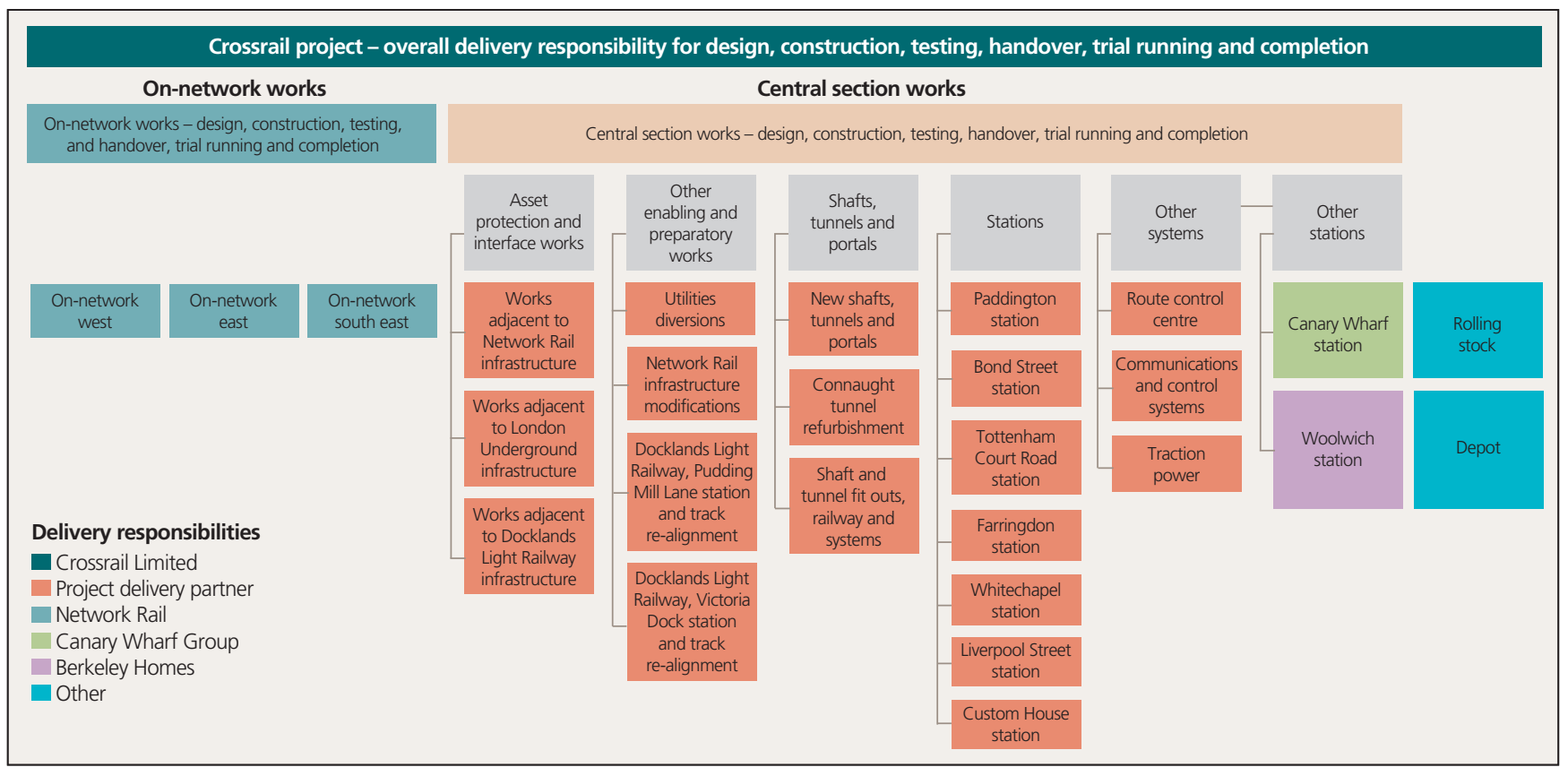

Figure 2. Scope by delivery responsibility 
Although some of the scope was delivered by third parties, contractually Crossrail Limited remained accountable to its sponsors for the overall delivery of the whole railway and accountable for overall systems integration. This latter role was a decision taken early on and had very wide-ranging consequences. The alternative, to hire a private contractor to take accountability for overall railway integration, was not believed to deliver value for money - if indeed a company could be found to take it on at all.

By becoming the railway integrator, Crossrail Limited also became responsible for planning the overall testing and commissioning work and for finally assembling the safety case to be submitted to the Office for Rail and Road, the statutory rail regulator.

\section{Sponsors' requirements}

The project has two sponsors, namely the UK's DfT and London's transport authority, TfL. The relationship between these entities and Crossrail Limited is governed by agreements which define the overarching requirements and the role each party fulfils in the delivery of the railway transport system, as illustrated in Figure 3. These agreements are crucial in aligning all parties' objectives and providing the necessary protections to sponsors and the delivery organisation alike along with the definition of the high-level end-toend scope.

The Sponsor Agreement governs the relationship between TfL and DfT as joint sponsors regulating the composition of the Crossrail Limited board and setting out the project's core obligations. At the very top of the requirements hierarchy sits the Sponsors' Requirements, which includes the UK government's objectives in creating the project. These are formally bound into the primary contractual arrangement between Crossrail Limited and the sponsors, namely the Project Development Agreement. The sponsors set out 11 high-level objectives for the Crossrail project as follows.

1. Ensure planning, construction, commissioning and implementation of the service is consistent with the UK government's overall approach to provision of major transport infrastructure, as well as the London mayor's plans for development of London's infrastructure.

2. Support the UK transport secretary's plans for public transport provision.

3. Provide value for money at every stage.

4. Have robust cost-control mechanisms throughout.

5. Achieve a service capacity of 24 trains per hour using $200 \mathrm{~m}$ trains.

6. Optimise whole-life cost over 50 years.

7. Establish and implement quality assurance, environmental assurance, safety and security regimes during design, construction, commissioning and service operation.

8. Ensure design complies with all applicable laws and applicable standards.

9. Deliver world-class levels of performance and reliability.

10. Deliver pro-active and consistent communications and relations with stakeholders, the media and local communities.

11. Achieve all outputs for a minimum of 50 years.

The agreement also prescribed how the sponsors engaged the company to deliver the project along with mandating a series

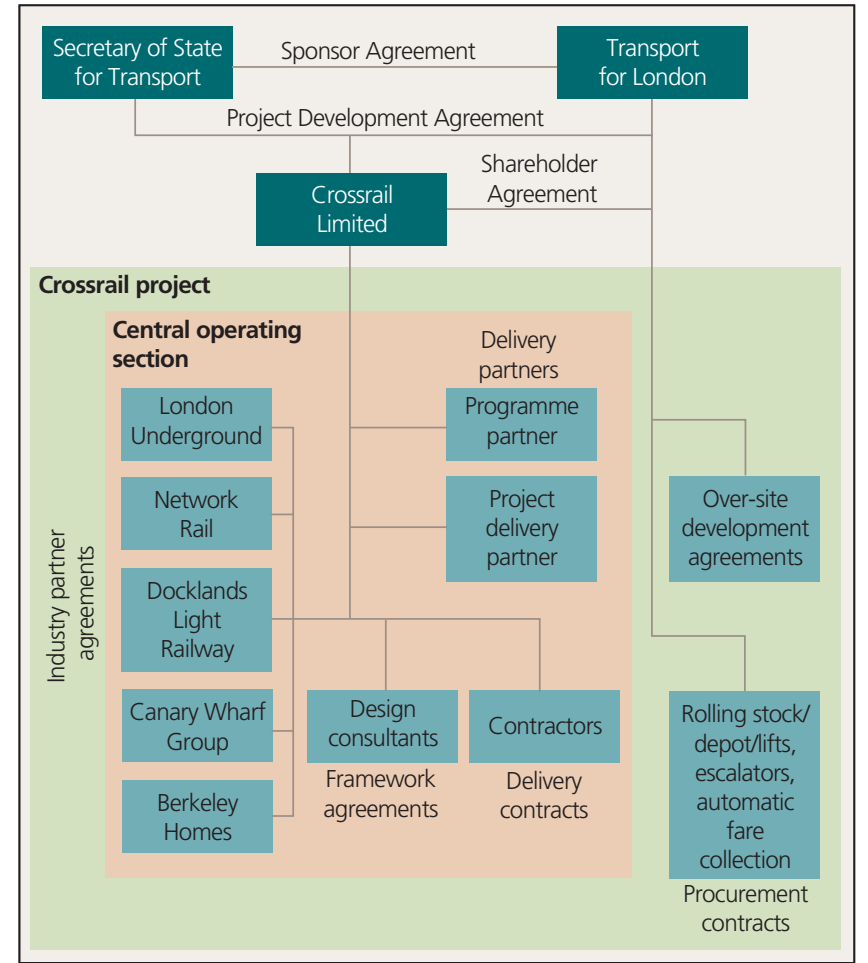

Figure 3. Contractual relationships

of review points whereby the project leadership team must demonstrate particular aspects of its maturity and capability for delivering the requirements.

The agreement drove the development of Crossrail Limited's organisation, assurance, governance and management capability in good time before works commenced. This foundation included Crossrail Limited's assurance process to verify for its management, the operators and its sponsors that it was delivering to the requirements, a task not made easy by the duration, scale and complexity of the project.

The challenge was addressed by ensuring that the requirements, and the assurance obligations, were scoped and procured within both the design and works contracts. Figure 4 sets out how the flow of assurance requirements is transferred into the supply chain contracts.

\subsection{Assurance}

In addition to the industry standard 'three lines of defence', the project is further assured through a fourth and fifth line of defence from its sponsors through representation and external scrutinising authorities, as illustrated in Figure 5.

The assurance process is the collective mechanism which integrates the Crossrail Limited organisation, its governance framework and the management and control systems which form the backbone of the project's controls functions around time, cost, risk, quality and reporting, as outlined in Figure 6.

To drive the high level of performance sought by sponsors, a performance assurance framework was developed to measure performance improvement, drive collaboration and share 
Civil Engineering

Volume 170 Issue CE6
Crossrail programme organisation and management for delivering London's Elizabeth line

Wright, Palczynski and ten Have

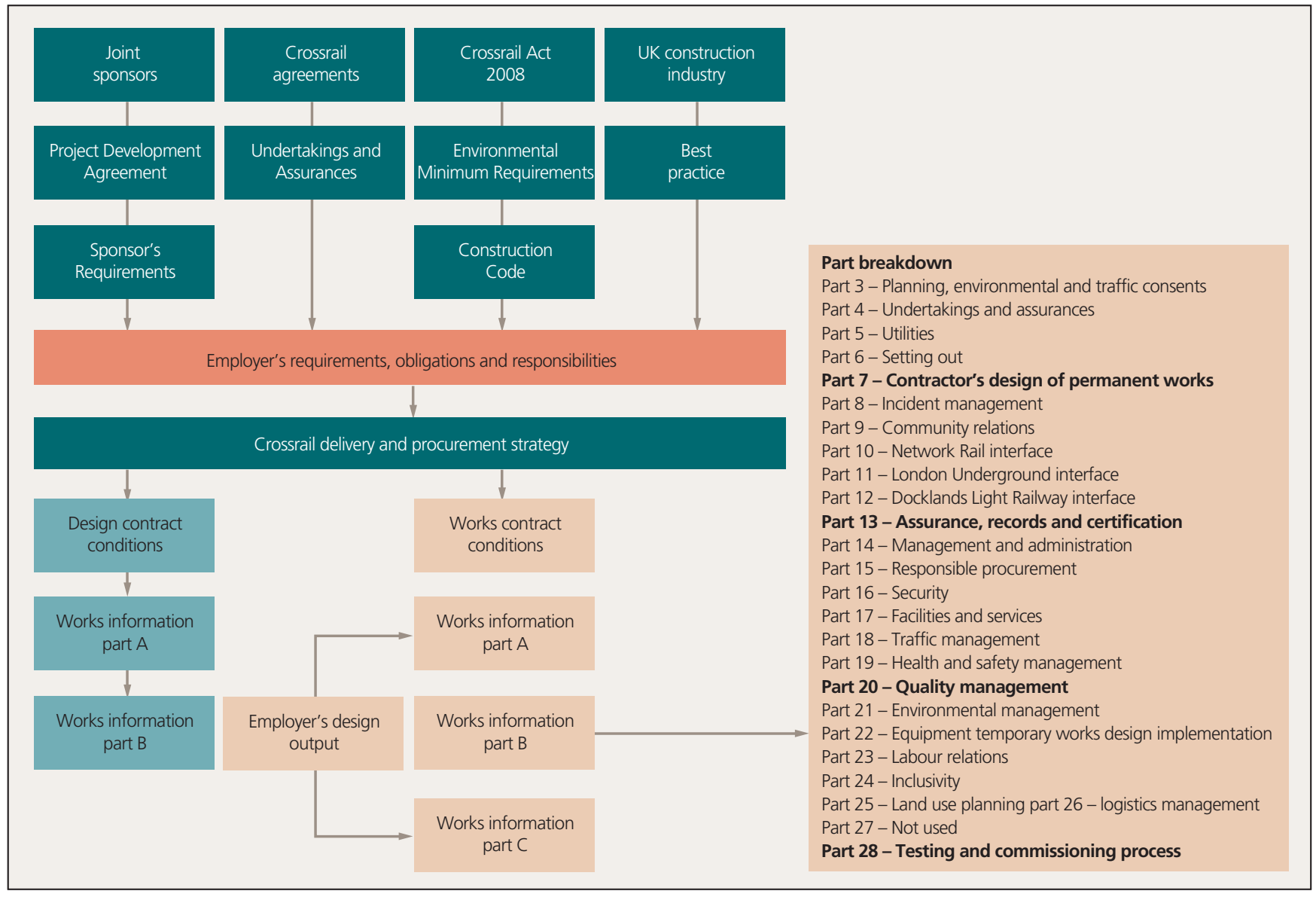

Figure 4. Project requirements flow

knowledge. The framework covered six key delivery functions which were embedded in the construction contract works information

- commercial

- health and safety

- quality (including technical compliance)

- environment

- community relations

- social sustainability.

Established in 2013, the performance assurance framework has supported a $54 \%$ increase in performance improvement across the supply chain, with several contractors demonstrating the ability to go beyond the minimum contracted standard and deliver either 'value added' or 'world class' performance. This method of measuring contractors' overall performance improvement through the life of a project, on a balanced-scorecard basis, helped to drive the behaviours that Crossrail Limited wished to encourage.

Accurate and timely information is the lifeblood of large projects and provides the management team with the knowledge as to what corrective actions are needed. Without this the leadership are unable to make informed decisions. Essential to the efficient running of this process are the digital systems and tools and how they were integrated.

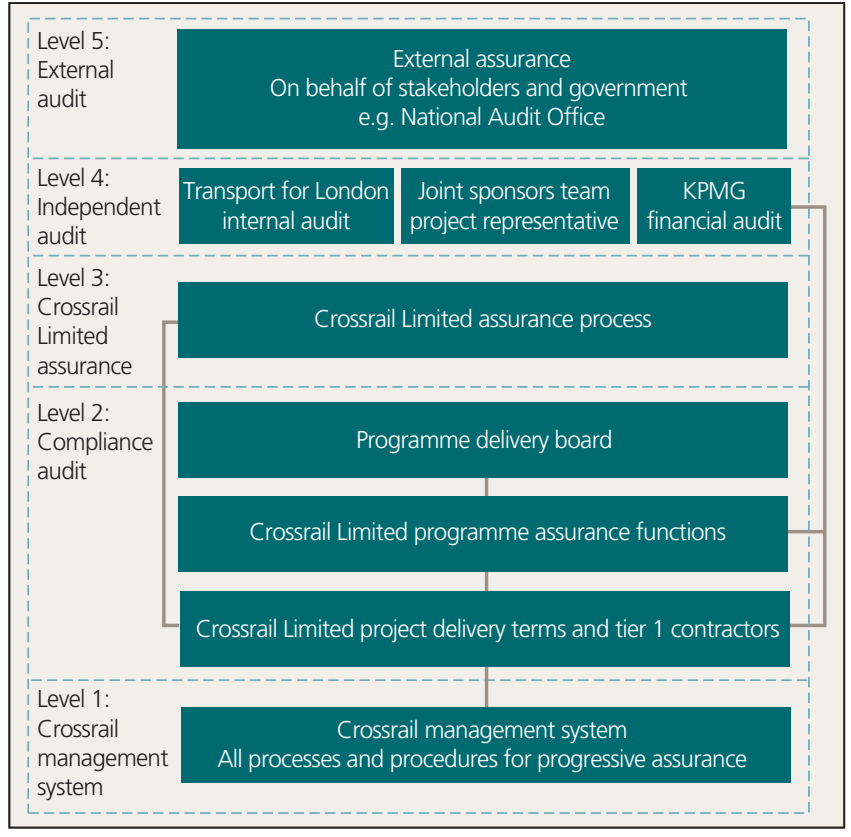

Figure 5. Levels of assurance 


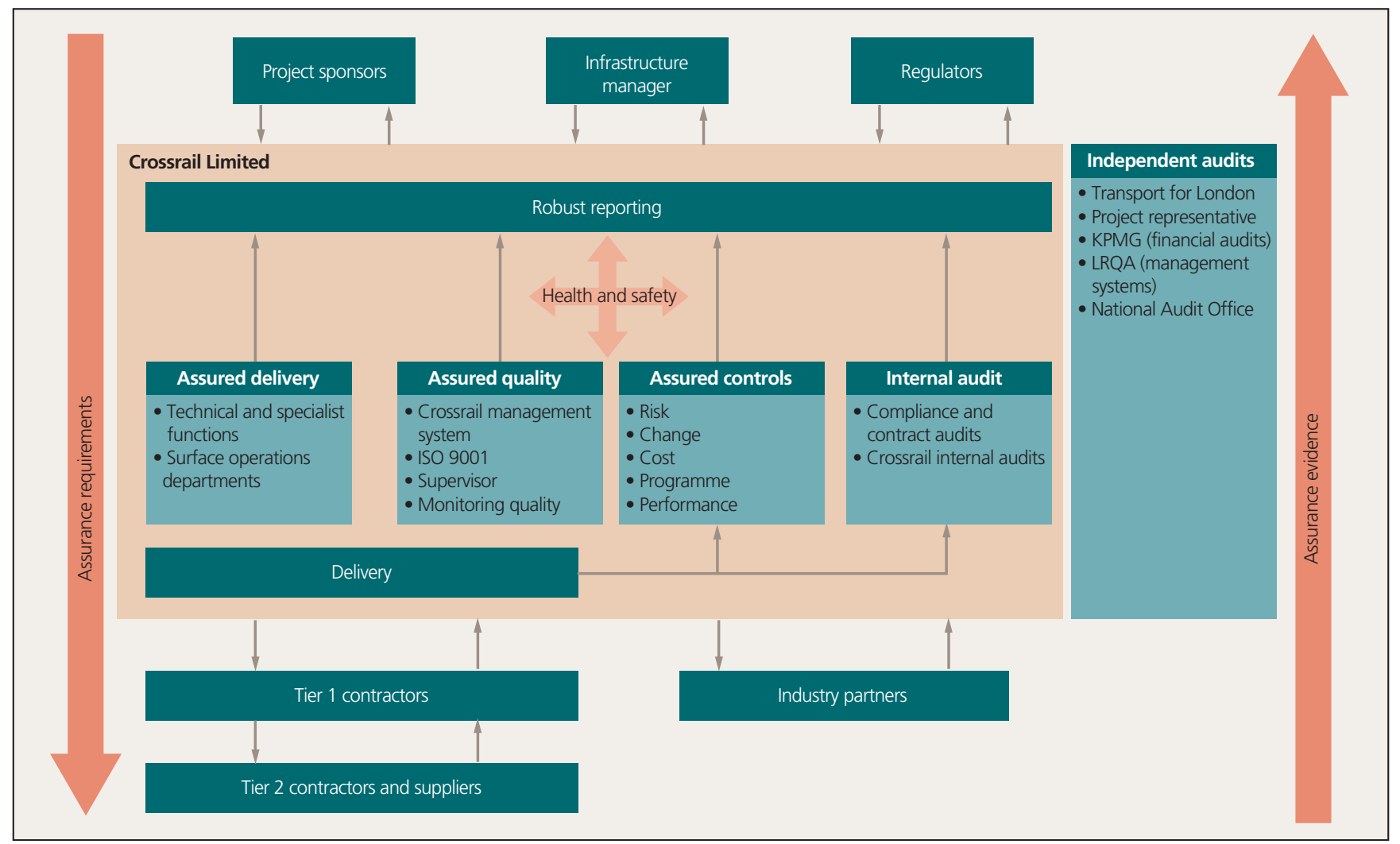

Figure 6. Assurance process

Figure 7 outlines the integrated digital platform developed for Crossrail Limited. With a minimum amount of customisation, the centrally held 'data warehouse' is the key to a successful reporting cycle which runs on a 4 week rolling periodic basis, and facilitates the production of all assurance data reports, including any ad hoc requirements out of the normal business-as-usual process. It allowed the conversion of a huge quantity of data into useful, succinct and timely management reports.

The sponsors set up a small 'joint sponsors team' to represent their interests and be the day-to-day point of contact with Crossrail Limited. Representing both DfT and TfL, the joint sponsors team meet with various representatives from the project on a regular basis, where any issues arising or areas of further information required are aired and discussed.

Underpinning the joint sponsors team, but working independently from the Crossrail project team, are the project representatives. Appointed by the joint sponsors team, the project representatives team, consisting of approximately 10 people, are tasked with acting as the independent assurance 'eyes and ears' of the joint sponsors team. They have a broad remit, are co-located in Crossrail's offices, can attend almost any meeting and ultimately form a completely independent assessment of performance across the project. Project representatives prepare a comprehensive report to sponsors on a 4 weekly cycle.

As with the sponsors, while project representatives are there to maintain the integrity of Crossrail Limited's reported position, the relationship is, and always has been intended to be, open, transparent and collaborative.

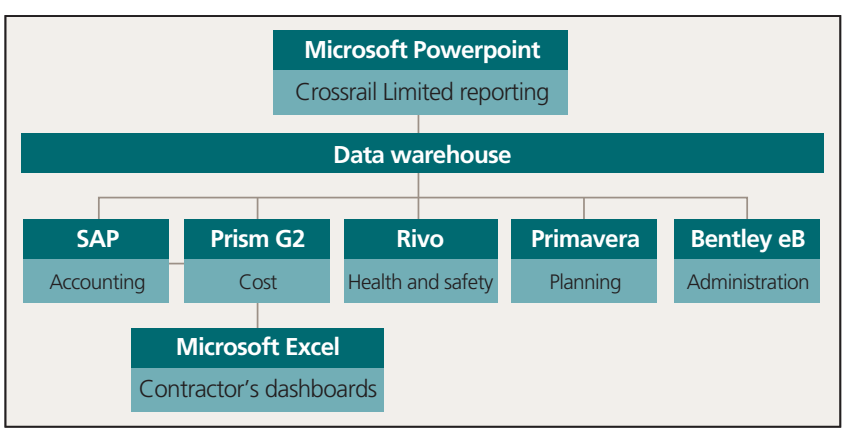

Figure 7. Data systems and tools

\section{Programme organisation}

\subsection{People and organisation capability}

Like other large-scale, long-term projects, the Crossrail Limited organisation has had to adapt to changes in the micro- and macroeconomic and political environment. Between royal assent in 2008 and handover to the operators in 2018 the project will have seen in three different London Mayors and three Prime Ministers.

Large programmes inevitably need to adapt as they go through the various phases of work and, for Crossrail Limited, this process is controlled by way of an annual business planning cycle, where the size and shape of the organisation are reviewed, challenged and 


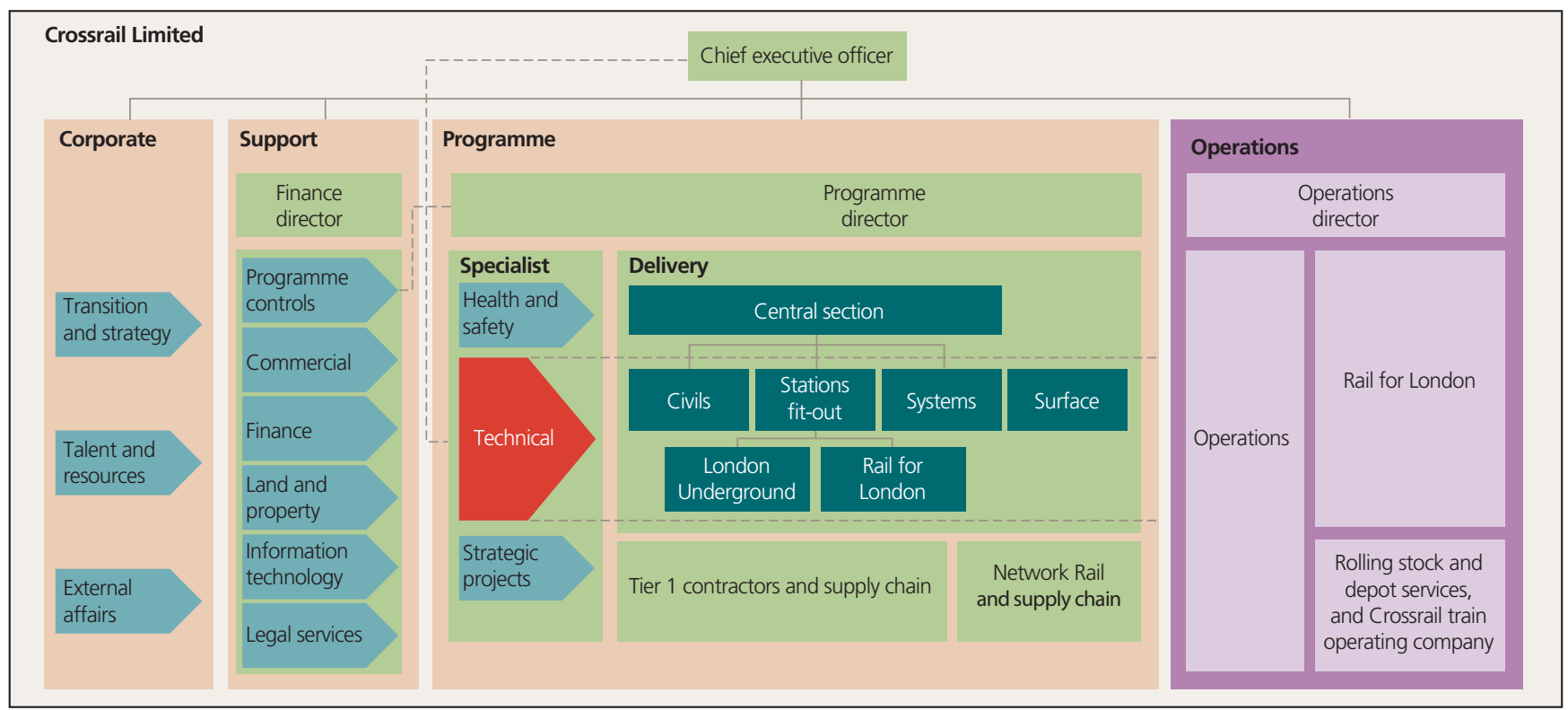

Figure 8. High-level organisation structure

reset for future years. Although fundamental to the smooth running of the project, the business planning work has not always been convenient and often a significant challenge when being worked in parallel to the day-to-day delivery.

However, the robustness of the process has always yielded the most efficient organisation - one focused on both the current and future phases of the project and able to demonstrate key staff were properly deployed and managed. The matrix management organisation structure adopted provided a good balance between accountability for time and money, but also was flexible enough to ensure delivery of the project progressed with the least amount of bureaucracy (see Figure 8).

Being a project of sizeable scale, the matrix organisation needed to ensure that its identity remained foremost a delivery focused project supported by its corporate and functional teams, and not the other way around. Over the course of 10 years, the project's leadership teams will have had to navigate their way through five such restructuring changes. Each change was introduced to suit a significant shift in the phase of the project, as seen in Figure 9.

With the award of both the programme partner and project delivery partner contracts in 2009, each organisation brought immediate tangible benefits. Examples include tools and processes including design management, performance measurements techniques, contract management, programme controls, cost management and reporting. But the real and most significant benefit was access to competent people with relevant major project experience to supplement the recruitment that Crossrail Limited staff themselves were carrying out.

This organisation supported the needs of the project for a period of 2 years, that is design, procurement and implementing programme controls systems, following which it was decided that a more integrated structure was needed to drive common goals and behaviour to focus on the future phases. Supported by a new organisation strategy, this new integrated management team would see all three entities coming together as one, adopting an approach of 'best person for the role' as depicted in Figure 10.

A hallmark of the restructuring was the flexibility of the structure, which enabled the leadership teams to maintain accountability and control of assurance and governance frameworks.

\subsection{Governance}

On any project, the primary requirement must be the ability to make clear decisions in an effective and timely manner. The term 'governance' does not fully reflect the challenges and difficulties associated with how, on a project of this scale, decisions at each level of the organisation get made.

But for over 7 years since the Crossrail Limited board first sat, Crossrail Limited has been running an established and

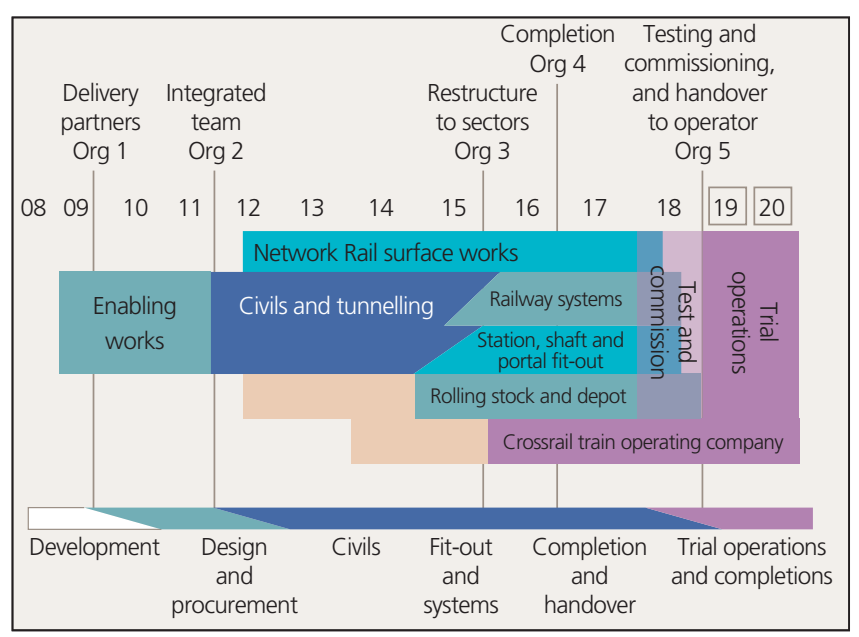

Figure 9. Evolution of the organisation 
Civil Engineering

Volume 170 Issue CE6
Crossrail programme organisation and management for delivering London's Elizabeth line

Wright, Palczynski and ten Have

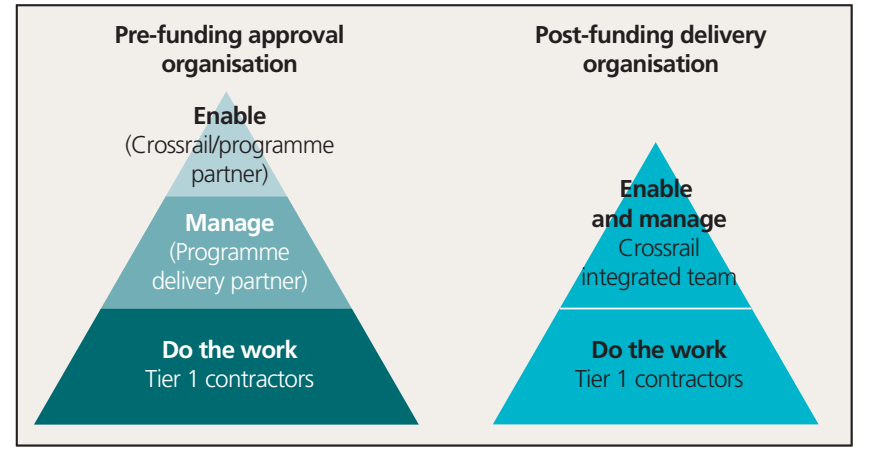

Figure 10. Transition to a single integrated organisation

comprehensive governance structure that is understandable, reliable, accountable and, when necessary, flexible to deal with the technical and commercial issues. Crossrail needed to implement a governance structure that both respected the scale of the organisation needed to deliver the project, and could evolve over the years to adapt to the changing circumstances.

Figure 11 illustrates the programme governance map, and outlines two very important differences embedded within the governance model - corporate governance and operational governance.

\subsubsection{Corporate governance}

The Crossrail Limited board is accountable for the overall direction and management of the organisation to ensure the project is delivered in accordance with its statutory and contractual obligations and in line with the UK Corporate Governance Code.

It remains the ultimate decision-making authority for driving the project forward by delegating this responsibility through the executive structure to the appropriate level, and also sets the agenda for the rest of the organisation's operational and functional teams.

\subsubsection{Operational governance}

Operational governance operates across the three levels below corporate governance, beginning with programme, then sector (formerly area) and then finally at project level. The framework aligns well with the organisation's accountability and responsibility matrices and uses a scheme of authorities which defines delegated levels of financial, contractual and payment limits for accountable individuals.

As with the organisational structure, the project leadership team has from time to time challenged its own governance model and tested its limits to determine if it remains fit for purpose. At several times throughout the history of Crossrail Limited, significant changes have been made to strategic meetings including applicability, format, attendance, frequency or a combination of all four. This has proved to be an effective means of applying a

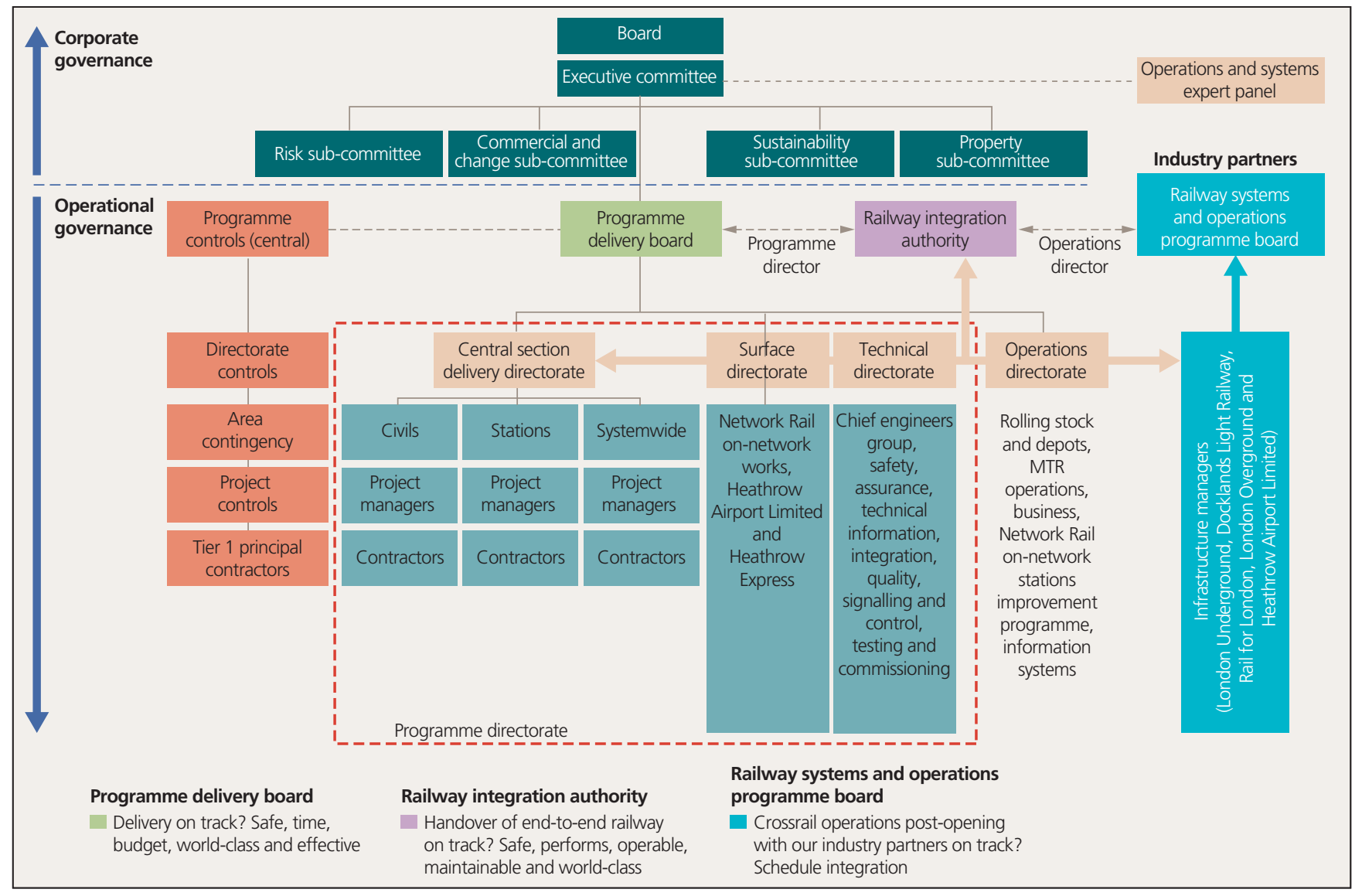

Figure 11. Governance map 
stringent approach to keeping things simple and ensuring project and programme management remains as efficient as possible.

\subsection{Programme controls}

Effective controls are the enabler of effective project and programme management. The term 'controls' often means different things to different organisations, but for Crossrail Limited, it includes cost management, schedule management, risk management, the performance management baseline, change control, performance analysis and finally reporting.

\subsubsection{Defining the work-breakdown structure}

One of the first priorities for Crossrail Limited, before any contracts could be procured, was to build and implement a coherent work-breakdown structure that would form the backbone of how the programme would be packaged and delivered. The work-breakdown structure was created by Crossrail Limited and applied across the entire programme, forming a fundamental component of the contractual works information document and the structure of its delivery teams. It was envisaged that all parties responsible for works delivery would use the work-breakdown structure consistently across their respective work scopes and data sets.

It was recognised early on that some simple, practical considerations would drive the team to the adoption of a high-level geographical split between works in the west, centre and east of the central operating section. Figure 12 illustrates how splitting the programme into three geographical areas meant that each area could oversee works of a similar scale. For example, each section would have a minimum of two tunnel boring machines (Ada and Phyllis in the west, Elizabeth, Victoria, Ellie and Jessica in the central section and finally Mary and Sophia in the east) and a reasonable split of the new stations to be built, with four stations in the west, three in the central section and two in the east.
In 2015 the programme made a fundamental switch in the workbreakdown structure to focus on disciplines (sectors) instead of geographical 'areas'. The switch happened in conjunction with an organisational change to ensure continuous alignment between the organisational breakdown structure and the work-breakdown structure. Making this switch recognised the fundamental shift in the physical works on site, with much of the heavy civil engineering (tunnels, excavation, sprayed concrete, etc.) completed and the mechanical and electrical fit-out now stretching across the entire route end to end.

Having established the work-breakdown structure and the contracting strategy for the way in which the works were to be delivered, the cost-breakdown structure and delivery organisational structure were designed to support the delivery of the workbreakdown structure. Figure 13 describes the current sector-based alignment between the work-breakdown structure, cost-breakdown structure and organisation-breakdown structure and, through the pyramid hierarchy, the scale of breakdown between the various layers.

\subsubsection{Staying on time}

The Crossrail project has always had a master programme or schedule, as illustrated in Figure 14. Initially entitled the master control schedule, it is the single guiding document that forms the backbone of every time-related review carried out on the project, and any failure to meet compliance with dates held in the schedule is immediately flagged as a critical issue. As the project moved towards completion and handover, the master control schedule was renamed appropriately as the master operations and handover schedule.

Maintaining a schedule commensurate with such a large-scale and high-profile project requires strict adherence to planning standards. One obvious departure from the typical rule book is that, unlike most projects, Crossrail Limited does not resource

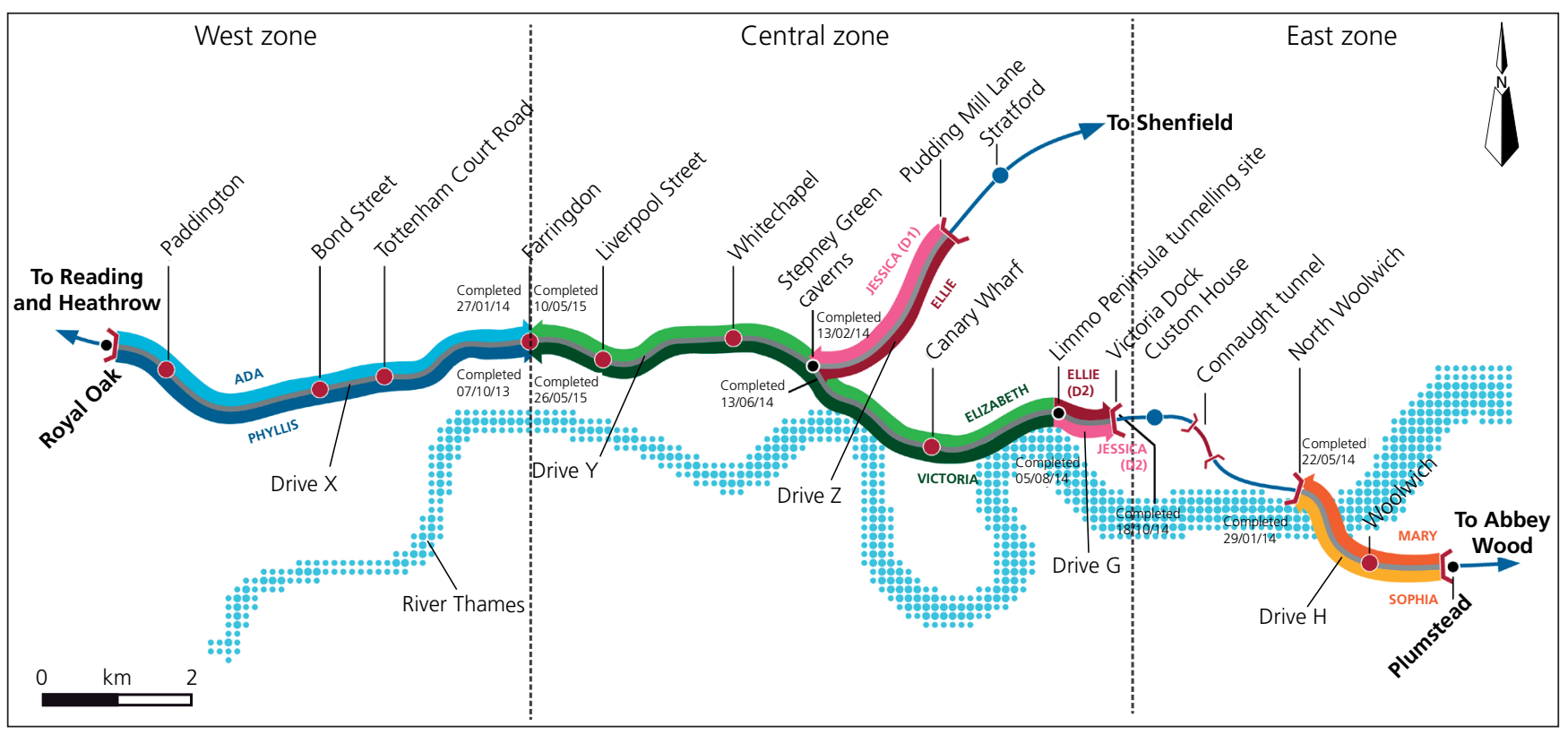

Figure 12. Geographical split of tunnelling and stations contracts 
Civil Engineering

Volume 170 Issue CE6
Crossrail programme organisation and management for delivering London's Elizabeth line

Wright, Palczynski and ten Have

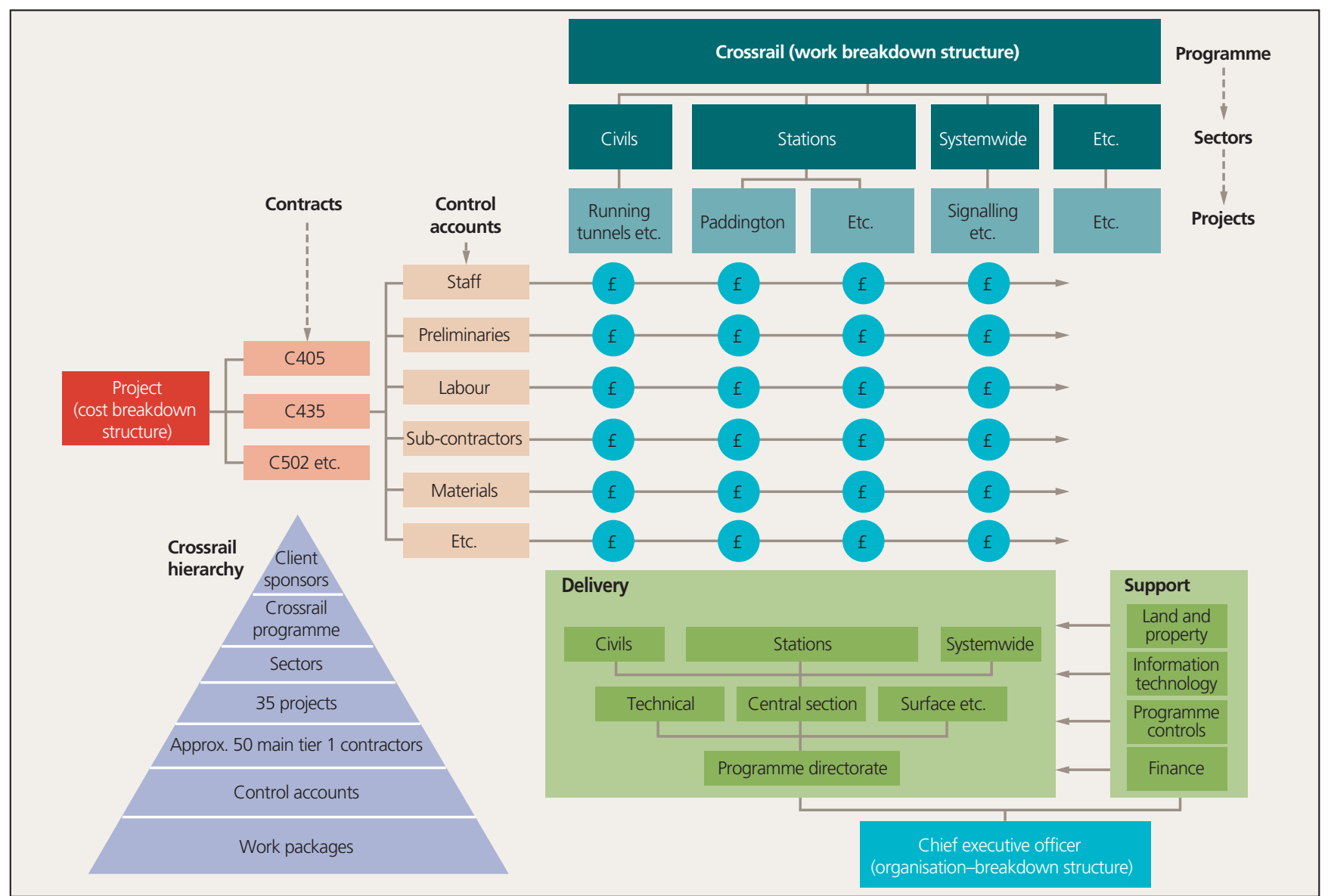

Figure 13. Work-, cost- and organisation-breakdown structures

load the activity schedules. The management of resources across the work-breakdown structure is owned and maintained by the cost-control function, which has the advantage of allowing the planning disciplines to focus purely on planning activities. Consisting of approximately 5000 activities, the master operations and handover schedule forms the level 1 integrated schedule, as outlined in Figure 15.

Managed in parallel to the maintenance of master operations and handover schedule is a bi-annual schedule quantitative risk assessment to derive the percentage confidence of meeting the key commissioning stage dates. This information forms one of several key performance indicators that are used by the sponsors and Crossrail Limited management to monitor progress against objectives.

\subsubsection{Staying on budget}

The initial control baseline estimated the price of the works nearer to $£ 18$ billion. The costs associated with the project have since been steadily refined through each of the major phases. By the time the physical works commenced in 2009 , the anticipated final cost for the project had reduced to $£ 15.9$ billion.

After the initial pricing, the project was procured immediately following the start of the global financial crisis, and certainly contractors' prices fell sharply as they competed aggressively to secure long-term major construction packages. The Crossrail

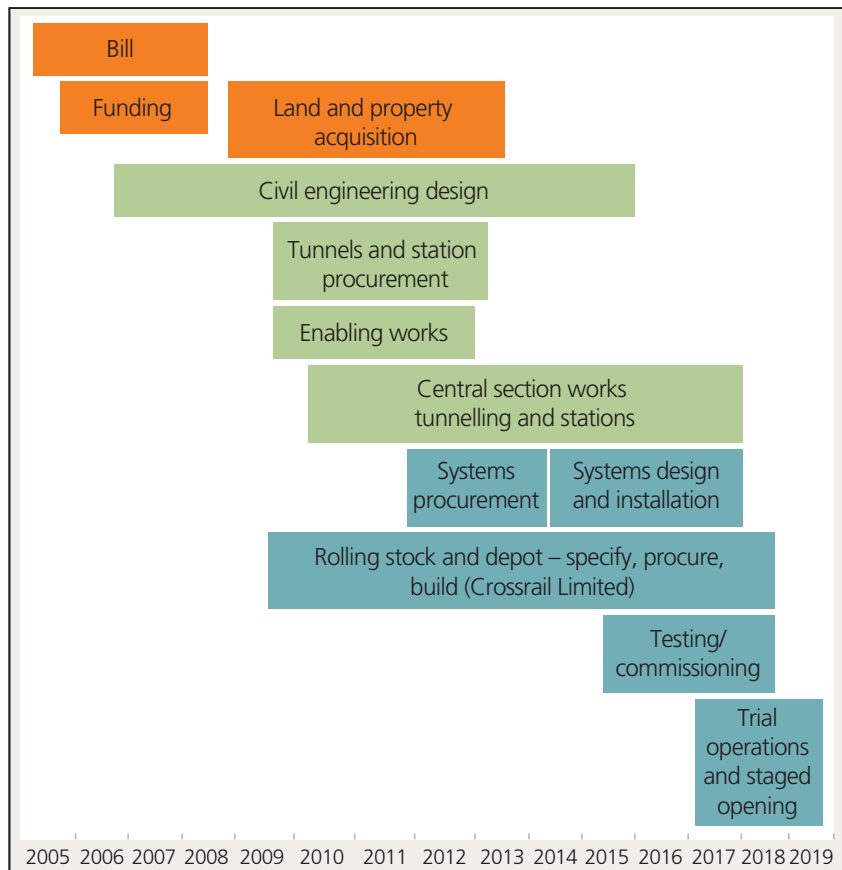

Figure 14. High-level schedule 


\begin{tabular}{|c|c|c|c|c|}
\hline $\begin{array}{l}\text { Level 0: } \\
\text { 100 } \\
\text { activities }\end{array}$ & & & Strategic plan & \\
\hline $\begin{array}{l}\text { Level 1: } \\
\text { 5000 } \\
\text { activities }\end{array}$ & & & \multicolumn{2}{|c|}{$\begin{array}{l}\text { Master operational } \\
\text { handover schedule }\end{array}$} \\
\hline $\begin{array}{l}\text { Level 2: } \\
\text {-30 000 } \\
\text { activities }\end{array}$ & & $\begin{array}{l}\text { Integrated } \\
\text { project } \\
\text { schedule }\end{array}$ & $\begin{array}{l}\text { Integrated } \\
\text { project } \\
\text { schedule }\end{array}$ & $\begin{array}{l}\text { Integrated } \\
\text { project } \\
\text { schedule }\end{array}$ \\
\hline $\begin{array}{l}\text { Level 3: } \\
\text { 300 } 000 \\
\text { activities }\end{array}$ & $\begin{array}{l}\text { Contractor } \\
\text { schedule }\end{array}$ & $\begin{array}{l}\text { Contractor } \\
\text { schedule }\end{array}$ & $\begin{array}{l}\text { Contractor } \\
\text { schedule }\end{array}$ & \\
\hline
\end{tabular}

Figure 15. Master operations and handover schedule and approach to integrated planning

Limited team, however, maintained a realistic approach to estimating. By working closely with the sponsors, cost estimates were rigorously held and, by taking a quantitative risk-based approach, were fully understood, including where the major uncertainties lay in the pricing.

As a result, a robust cost range or 'funding envelope' within which to work was established. This distinct difference in set-up - a pragmatic approach from the sponsors to recognise that uncertainty exists - allowed Crossrail Limited to be released from the burden of working to a single fixed figure. In adopting this more modern approach, Crossrail Limited was able to maximise opportunities for decision making rather than being constrained by a number and was able to openly acknowledge that realistic fluctuations are to be expected.

In 2010, following the appointment of the new coalition government, a national comprehensive spending review was undertaken, which challenged all public-funded infrastructure projects to make savings. Crossrail was not exempt.

In response, the delivery team undertook a full optioneering study and by November 2010 was able to hand back over $£ 1$ billion in forecast costs due principally to a revision of the tunnelling strategy. This meant that the completed railway services would now commence through the central section in December 2018 rather than 2017, followed by a phased introduction of services across the rest of the route but the scope of the project was not reduced.

The re-scheduling allowed the funding envelope needed to deliver Crossrail Limited to be revised to $£ 14.8$ billion from $£ 15.9$ billion and was a fully inclusive cost, allowing for both contingency and expected inflation. This figure has remained unchanged since 2010 .

\subsubsection{Cost management}

With a spend rate of approximately $£ 24$ million per week, it has been essential that Crossrail Limited take an extremely robust approach to cost management and change control. To enable this to happen, a series of short but very precise procedures were created and, from day 1 , embedded in the contract works information. In a single stroke, Crossrail established consistency across the project and its supply chain.
To bring everything together, Crossrail established a 'single source of the truth', by developing a comprehensive costbreakdown structure in the cost management system that paired with the work-breakdown structure in the planning tools. As with the management of governance and the organisation itself, a 6 monthly review has always ensured that the systems remain fit for purpose and that they do provide transparency and legacy data as and when needed.

\subsubsection{Collaboration through NEC3 contracts}

As with most UK major construction projects, the decision to use the Institution of Civil Engineers' NEC3 suite of contracts was a logical choice. Crossrail Limited elected to employ the NEC3: Engineering and Construction Contract Option C, which is a target-price contract with a pain/gain mechanism, and developed its procurement strategy accordingly. This form was also widely used by the UK Olympic Delivery Authority for procuring venues and infrastructure for the London 2012 Olympic and Paralympic Games.

It was critically important for Crossrail Limited, as a client, to embark on an open, fair and collaborative approach with all its contractors, building consistency into the delivery by standardising the contract works information and setting consistent expectations across all construction sites. Like a lot of clients, Crossrail Limited started with the standard Engineering and Construction Contract and then elected to make certain changes through the introduction of $\mathrm{Z}$ clauses, for example to introduce value engineering and tighten up language around indemnities.

The volume of contracts required developing a bespoke suite of contract administration tools and databases, which have helped to control and efficiently record the massive volume of formal correspondence over the years. This system will help the project avoid a lengthy contract close-out process and achieve its goal of having all contracts commercially closed by the time the operators open the railway.

'BS 11000 1:2010 Collaborative business relationships. A framework specification' (BSI, 2010) (now BS ISO 44001:2017) did not exist in 2009 so collaboration on the Crossrail project was built on the premise of shared opportunity and shared accountability through a target-cost-driven contracting model. This is how the relationships were established and is how they are managed today.

Crossrail Limited has chosen to adopt many of the principles embedded within BS 11000 and considerable effort is made at all levels to manage each relationship and to maintain open lines of communication, encourage sharing and best practice across relationship boundaries and to encourage the use of lessons learned on new contracts as they have emerged over time.

\subsubsection{Managing the risk}

As a fundamental part of its assurance to sponsors risk, management has been at the forefront of the approach to delivering the project. During the development phase, much time was spent identifying the strategic risks to which the programme would be exposed. Many of the concerns raised during the bill phase were translated into commitments, obligations and requirements, and accordingly formed a significant portion of the strategic risk base. 
The accurate cost estimation of any major infrastructure project is fundamental to the justification of the business case and the assembly of adequate funding. An estimate must be established very early in the project lifecycle when many uncertainties still exist. Rather than building a cost model based on employing the UK government's traditional optimism-bias approach, the Crossrail Limited team instead moved to take a quantitative risk-based approach, choosing to build complete models and strive to fully understand where the uncertainties lay and what the associated risks were.

The more innovative approach to managing the cost associated with uncertainty allowed the sponsors to remain fully engaged in the process as well as facilitating some of the technical decision making necessary at the time. It is this inclusion with the sponsors that many on the project feel was a major consideration in the project successfully defending the cost and programme schedule. As the sponsors were actively engaged in the process, they consequently fully understood what was required by the programme team to deliver the works successfully.

This emphasis on risk management remained fundamental to the approach as the programme moved from the development phase into the delivery phase. The Crossrail Limited team instilled a risk management culture so that as more and more multi-disciplinary designers came on board, risk management was embedded into their thinking from the start; designers were focused on designing out risks and uncertainty as opposed to inadvertently building them in.

As the delivery phase moved from design into construction, the emphasis on risk management shifted focus. Having implemented the strategy, policies, tools and reporting, the next requirement was to drive risk management down into the supply chain.

For instance, in the area of technical risk management, the adoption of one key document - The Joint Code of Practice for Risk Management of Tunnel Works in the UK produced by the Association of British Insurers and the British Tunnelling Society (ABI and BTS, 2003) - made risk management a fundamental tenet of working practices on all tunnelling and underground contracts, and has remained so throughout the works.

\subsubsection{Reporting}

Essential to Crossrail Limited is the reporting cycle around which it operates. Based on 13 rolling 4-week periods per year, Figure 16 depicts the 6 weeks it takes to move performance management data from their origin with the contractor all the way through to the Crossrail Limited board and the sponsors.

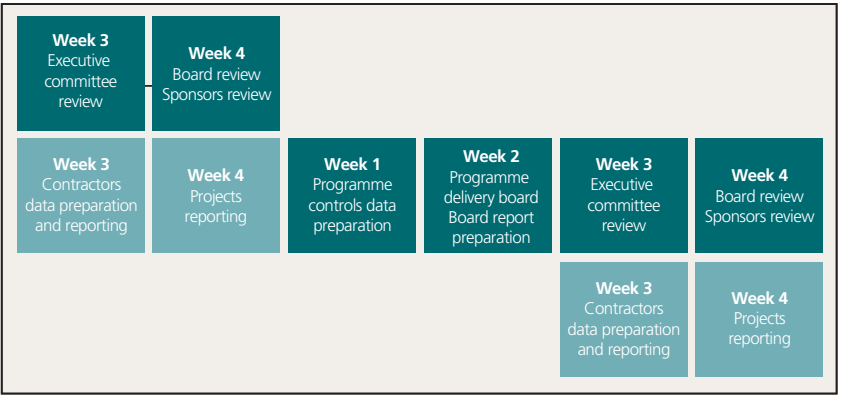

Figure 16. Reporting cycle
As set out within the governance arrangements, the programme delivery board is the single most important vehicle for performance management and intervention. Spread across 2 days chaired by the programme director, the forum is a controlled review of each major contract on the project.

It affords the leadership team the opportunity to scrutinise the status of each part of the project, all of which provides valuable insight and feedback for the executive committee and board reports and subsequent meetings. The reviews are structured around a single-page standardised project dashboard.

\section{Conclusion}

Crossrail Limited's approach to project and programme management has sought to set the bar for major infrastructure delivery, not just in the UK but globally. Its success to date is largely down to getting the basics right from the start. That meant

- having a plan that is clear and based on a well-documented set of customer requirements

- employing the right number of the right people for the job

- keeping things simple and flexible

- identifying and managing the risk by always 'looking around the corner'

- making the key dates unmoveable deadlines to be met.

The development of effective project controls with regular 4-weekly management reports containing accurate information allowed a focus on the key issues and challenges. An effective governance structure, which was kept under regular review, also led to efficient and timely decision making which kept the programme moving forward.

As a special-purpose client organisation, the adoption of a partnering approach to organisational delivery certainly proved effective in allowing the Crossrail Limited board and leadership team to maintain their focus on stakeholder management and project delivery.

Crossrail Limited is continuing to forecast delivery within the funding envelope and to open the railway in stages on time. This has been achieved thus far because of the effort, commitment and professionalism of the thousands of men and women who have worked on the project.

\section{References}

ABI and BTS (Association of British Insurers and the British Tunnelling Society) (2003) The Joint Code of Practice for Risk Management of Tunnel Works in the UK. BTS, London, UK.

BSI (2010) BS 11000-1:2010 Collaborative business relationships. A framework specification. BSI, London, UK.

Crossrail Act 2008. Chapter 18. Her Majesty's Stationery Office, London, UK.

\section{How can you contribute?}

If you would like to comment on this paper, please email up to 200 words to the editor at journals@ice.org.uk. 